Bangladesh J. Zool. 40(1): 43-50, 2012

\title{
COMPARISON OF ESTERASE ISOZYME VARIABILITY IN SOME SELECTED TISSUES OF THE ASIAN AND AFRICAN CATFISHES (SILURIFORMES: CLARIIDAE)
}

\author{
Rowshan Ara Begum, Dilshad Tamanna Rahman, Md. Abdul Rashid, \\ Md. Shamimul Alam and Reza Md. Shahjahan* \\ Department of Zoology,University of Dhaka, Dhaka-1000, Bangladesh
}

\begin{abstract}
Variation in esterase isozymes expression of 19 different tissues of the Asian catfish (Clarias batrachus) and African catfish (C. gariepinus) was studied. These tissues were: liver, anterior muscle, mid muscle, tail muscle (ventral region), tail muscle (tip region), buccal muscle, stomach, foregut, midgut, hindgut, kidney, gill, heart, eye (lens), eye (black portion), pelvic muscle, fore-, mid- and hind-brain. Maximum five esterase bands, viz. Est-1 ${ }^{1.83}$, Est-2 ${ }^{1.50}$, Est-3 ${ }^{1.15}$, Est-41.00 and Est$5^{0.17}$ were observed in the Asian catfish and four bands, viz. Est-2 ${ }^{1.50}$, Est-3 ${ }^{1.15}$, Est-41.00 and Est-50.17 in the African catfishes. Tissue specific localization of the isozymes was observed in both Asian and African catfishes. Comparatively higher esterase activity was found in digestive tissues. Higher number of esterase bands was found in $C$. batrachus which seems to be an indication of its greater allelic variation in esterases than those in the C. gariepinus.

Key words: Esterase, isozyme, Clarias batrachus, C. gariepinus, tissue specificity, polyacrylamide gel electrophoresis
\end{abstract}

\section{INTRODUCTION}

The Asian catfish, Clarias batrachus (Linn., 1758) belonging to family Clariidae is a species of freshwater air breathing catfish found primarily in Southeast Asia and cultured as a food fish (Courtenay 1970, Sen 1985). On the other hand, C. gariepinus (Burchell 1822) is the native species of Africa. The species has drawn attention to aquaculturists because of its biological attributes that include faster growth rate, resistance to diseases and possibility of high stocking density.

Electrophoretic investigations of proteins and enzymes, especially allozymes as genetic markers, have been decisive in determining the taxonomic and population status of many organisms (Ferguson 1980). Allozymes have been particularly useful for identifying fish species and their hybrids in natural and artificial populations (Ferguson et al. 1995, Aylton and Suzana 2005). Isozyme patterns show pronounced differentiation in many organisms including fish (Reinitz 1977, Solomon and Child 1978, Ferguson 1980). Isozyme analysis has been used to estimate the genetic variation between different populations of fish species (Barua et al. 2004), and also to develop a genetic sexing system (Robinson 1986). Esterase isozyme is one of the lipid-hydrolyzing enzymes which

*To whom all correspondence should be made. E-mail: reza_shahjahan@yahoo.com 
has a great significance in the field of genetics and toxicology (Callaghan et al. 1994) and can be separated by electrophoresis at different isoelectric points. Correlation has been made in several fish species between the presence of this enzyme with fat digestion and lipid absorption (Baglole et al. 1998). This enzyme may be of particular importance because fishes utilize lipid/fat as their main nutritional source rather than carbohydrate and protein, especially during the later developmental stages (Baglole et al. 1998). Literature search reveals a number of works on the genetic variability of the genus Clarias. Na-Nakorn et al. (2002) reported isozyme variability in four species of Clarias, viz. C. batrachus, C. gariepinus, C. macrocephalus and C. meladerma. They used about ten enzymes system with polymorphic loci and tried to establish the genetic distance using dendrogram. Teugels et al. (1992), Teugels (1996), Rognon et al. (1998) also used isozymes for the identification of species Clarias and their attention was to analyze enzyme polymorphism and variation in polymorphic loci in the population.

The present study was attempted to find out tissue specific esterase banding patterns in the Asian catfish C. batrachus and African catfish C. gariepinus and to compare species-specific esterases between the two allied species.

\section{MATERIAL AND METHODS}

The present investigation on esterase isozymes pattern was carried out at the Genetics and Molecular Biology Laboratory in the Department of Zoology, University of Dhaka. The catfishes were collected from the fishermen of New market, Dhaka, Bangladesh. The specimens were then dissected to collect the following 19 tissues: liver, anterior muscle, mid muscle, ventral tail muscle, tip tail muscle, buccal muscle, stomach, foregut, midgut, hindgut, kidney, gill, heart, eye (lens), eye (black portion), pelvic muscle, fore brain, mid brain and hind brain. The technique for polyacrylamide gel electrophoresis (PAGE) was followed from Shahjahan et al. (2008). Esterases were identified in the gels following the technique described by Johnson and Denniston (1964).

\section{RESULTS AND DISCUSSION}

During the present study attempts were made to have a comprehensive picture of the different esterase bands which could be visualized in PAGE using the different tissue squashes collected from the different parts of the body and stained with both $\alpha$ - and $\beta$ - naphthyl acetates substrate. Altogether five esterase isozyme bands, viz. Est-11.83, Est-21.50, Est-31.15, Est-41.00 and Est-50.17 were observed. Est-1 denoted the band with the highest mobility (i.e. lowest molecular weight) and Est-5 the lowest mobility (i.e. highest molecular weight) (Richardson 
et al. 1986). The results made for the various esterase bands from C. batrachus and C. gariepinus were as follows:
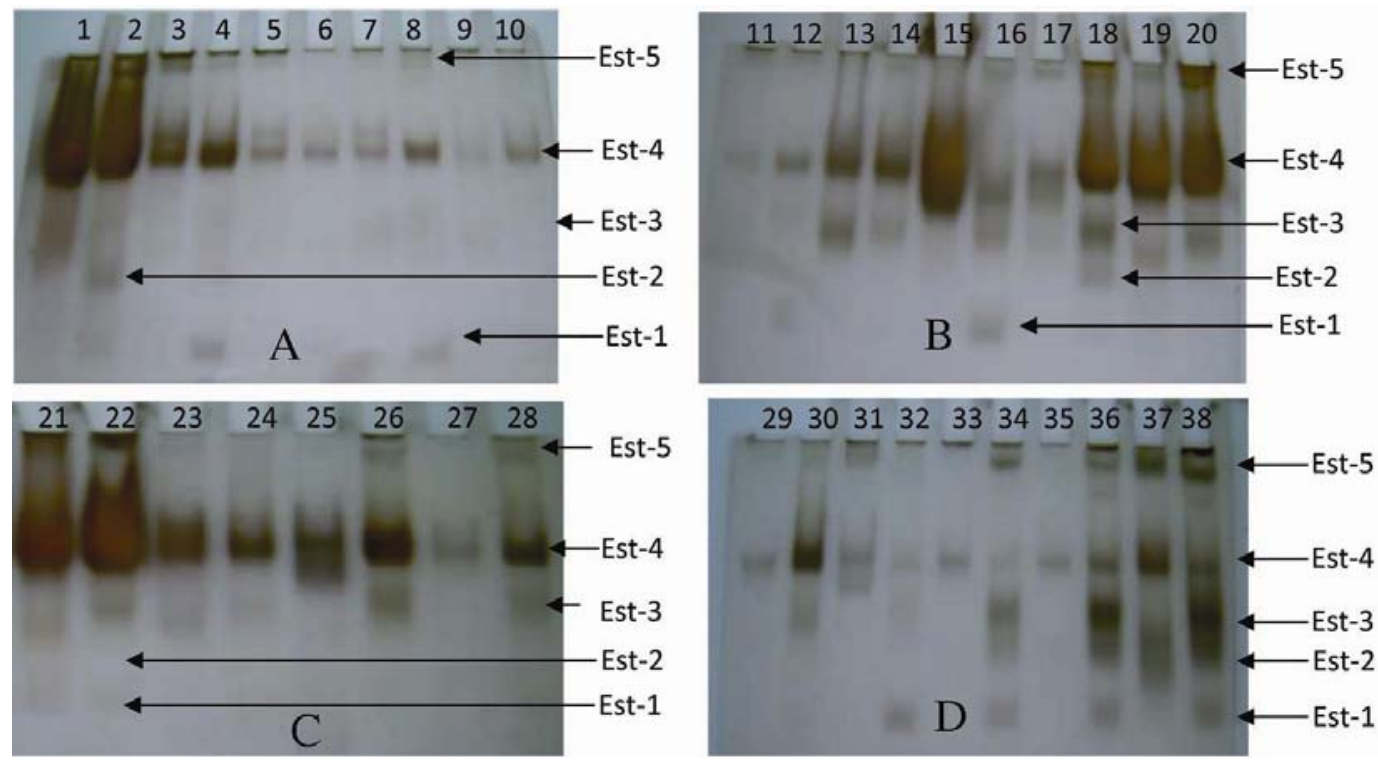

Plate 1A-D. Comparison of esterase isozyme banding patterns in different tissues of the Asian catfish (even lanes) and African catfish (odd lanes). Lanes $1 \& 2=$ liver; $3 \& 4=$ anterior muscle; $5 \& 6=$ mid muscle; $7 \& 8=$ tail muscle (ventral); $9 \& 10=$ tail muscle (tip); $11 \& 12=$ buccal muscle; $13 \& 14=$ stomach; $15 \& 16=$ foregut; $17 \& 18=$ midgut; $19 \& 20=$ hindgut; $21 \& 22=$ kidney; $23 \& 24=$ gill; $25 \& 26=$ heart; $27 \& 28=$ eye (lens); $29 \& 30=$ eye (black portion); $31 \& 32=$ pelvic muscle; $33 \& 34=$ fore brain; $35 \& 36=$ mid brain and $37 \& 38=$ hind brain. Esterase band numbers are shown by the arrow $(\leftarrow)$ marks.

C. batrachus: Altogether four esterase bands (Est-1, Est-2, Est-4 and Est-5) were found in the liver, three bands (Est-1, Est-4 and Est-5) in the anterior muscle and the ventral tail muscle, three bands (Est-1, Est-3 and Est-4) in the pelvic muscle, two bands (Est-1 and Est-4) in the mid muscle and two (Est-1 and Est-4) in the buccal muscle, only one (Est-4) band in the tip tail muscle, three bands (Est-3, Est-4 and Est-5) in the stomach, four bands (Est-1, Est-3, Est-4 and Est-5) in the foregut, four bands (Est-2, Est-3, Est-4 and Est-5) in the midgut and three (Est-3, Est-4 and Est-5) in the hindgut, three bands (Est-2, Est-4 and Est-5) in the kidney, two bands (Est-3 and Est-4) in the gill, three bands (Est-3, Est-4 and Est-5) in the heart, three bands (Est-3, Est-4 and Est-5) in the eye (lens), and three bands (Est-1, Est-3 and Est-4) in the black portion of eye and all five esterase bands (Est-1, Est-2, Est-3, Est-4 and Est-5) in the fore-, mid- and hind-brain of this fish species (Plate1A-D and Table 1). 
Table 1. Compatative electrophoretic banding pattern showing staining intensities of esterase isozymes in different tissues of Asian and African catfish scored from both $a$ and $\beta$ naphthyl acetate stained gel.

\begin{tabular}{|c|c|c|c|c|c|c|c|c|c|c|c|}
\hline \multirow{2}{*}{ Slot No. } & \multirow{2}{*}{ Tissues name- } & \multicolumn{2}{|c|}{ Est-1 1.83} & \multicolumn{2}{|c|}{ Est-21.50 } & \multicolumn{2}{|c|}{ Est-31.15 } & \multicolumn{2}{|c|}{ Est-4 1.00} & \multicolumn{2}{|c|}{ Est-50.17 } \\
\hline & & $a f^{*}$ & as* & af & as & af & as & af & as & af & as \\
\hline $1-2$ & Liver & - & + & + & ++ & - & - & +++ & +++ & - & +++ \\
\hline $3-4$ & A. muscle & - & ++ & - & - & - & - & +++ & +++ & ++ & + \\
\hline $5-6$ & M. muscle & - & ++ & - & - & - & - & ++ & ++ & + & - \\
\hline $7-8$ & T. muscle-v & - & ++ & - & - & - & - & ++ & +++ & - & + \\
\hline $9-10$ & T. muscle-t & - & - & - & - & - & - & + & ++ & - & - \\
\hline $11-12$ & B. muscle & - & + & - & - & - & - & + & ++ & - & - \\
\hline $13-14$ & Stomach & - & - & - & - & ++ & + & +++ & +++ & - & + \\
\hline $15-16$ & Foregut & - & + & - & - & - & ++ & +++ & ++ & - & + \\
\hline $17-18$ & Midgut & - & - & - & ++ & + & ++ & ++ & +++ & + & ++ \\
\hline $19-20$ & Hindgut & - & - & - & - & + & ++ & +++ & +++ & + & +++ \\
\hline $21-22$ & Kidney & - & - & - & ++ & ++ & - & +++ & +++ & +++ & +++ \\
\hline $23-24$ & Gill & - & - & - & - & + & + & +++ & +++ & - & - \\
\hline $25-26$ & Heart & - & - & - & - & - & ++ & +++ & +++ & - & ++ \\
\hline $27-28$ & Eye (lens) & - & - & - & - & - & ++ & + & +++ & - & + \\
\hline $29-30$ & Eye (ball) & - & + & - & - & - & ++ & ++ & +++ & - & - \\
\hline $31-32$ & P. muscle & - & ++ & - & - & ++ & + & ++ & + & ++ & - \\
\hline $33-34$ & Fore brain & - & ++ & - & ++ & - & ++ & ++ & + & - & +++ \\
\hline $35-36$ & Mid brain & - & ++ & - & ++ & - & ++ & + & ++ & - & ++ \\
\hline $37-38$ & Hind brain & - & ++ & ++ & ++ & - & +++ & +++ & ++ & +++ & +++ \\
\hline
\end{tabular}

*'as' and 'af' represent Asian catfish Clarias batrachus and African catfish C. gariepinus, respectively. '+', '++' '+++' and '-'denote faint, medium, deeply stained and absent of the band, respectively.

C. gariepinus: In this catfish only two esterase bands (Est-2 and Est-4) were found in the liver, three esterase bands (Est-3, Est-4 and Est-5) in the pelvic muscle, two bands (Est-4 and Est-5) in both anterior and mid muscles, only one band (Est-4) each in the ventral and tip of tail muscles as well as in the buccal muscle, two bands (Est-3 and Est-4) in the stomach, only Est-4 band in the foregut, three bands (Est-3, Est-4 and Est-5) in the midgut and three bands (Est-3, Est-4 and Est-5) in the hindgut, three bands (Est-3, Est-4 and Est-5) in the kidney and two (Est-3 and Est-4) in the gill, only one band (Est-4) each in the lens, black portion of eye and in the heart, only Est-4 band in fore- and mid-brain, and three bands (Est-2, Est-4 and Est-5) in hind brain (Plates A-D).

The expressions of esterase bands were tissue specific in both Asian and African catfishes. Maximum five esterase bands were observed in Asian catfish whereas African catfish showed four (Table 1). Harries et al. (1990) observed three polymorphic loci in shrimp, Penaeus vannameri. Eight esterase bands were observed in different tissues of Oreochromis aureus (Hongtuo et al. 1993). Knowles et al. (1968) reported six esterase bands in the brain of Channel catfish 
Ictalurus punctatus. Shahjahan et al. (2008) examined the electrophoretic banding pattern of esterase isozymes in 18 different tissues of $O$. niloticus, where they observed five bands. Begum et al. (2008) found a total of five esterase bands in 19 different tissues of Pangasius hypophthalmus. Seven esterase bands were reported in blunt snout lorean fish (Sifa et al. 1993).

Tissue-specific esterase isozyme variation was observed in both Asian and African catfishes. The localization of the isozymes was clearly visible in different tissues (Plates A-D). In C. batrachus the maximum number of bands was observed in liver and brain tissues (Est-1, Est-2, Est-3, Est-4 and Est-5) and the minimum in the tip tail muscle (only Est-4). In C. gariepinus altogether four bands (viz. Est-2, Est-3, Est-4 and Est-5) were found in different tissues. Some tissues (viz. midgut, hindgut, kidney, pelvic muscle and hind brain) contained three bands. On the other hand, single band was present each in foregut tail muscle, heart, eye, fore brain and mid brain. Tissue specific expression of esterase was also found in xiphophorine fishes Platypoecilus maculates, Xiphophorus helleri and their F1 hybrid, where seven esterase zones resolved into maximum nine bands (Ahuja et al. 1977). As for example relatively higher concentration of esterase isozymes were found in digestive tissues. Hirji and Courtney (1983) found strong enzymatic activity in the upper and middle portion of the intestine whereas weak in the lower intestine of the perch fish Perca fluviatilis. Specific allele in specific tissues shows esterase activity due to biological need of that tissue specific function. Witzemann and Boustead (1981) investigated that the location and function of the various esterase forms can vary from tissue to tissue and depend on the physiological demands of each system.

A comparative study revealed that esterase isozymes banding pattern in different tissues of the two catfishes has both similarity and dissimilarity in their staining intensity as well as in the occurrence of the number of bands (Fig. 1). Est-1 was not observed in the 19 tissues of the African catfish which appeared to be specific to the Asian catfish. As the electrophoretic pattern of esterases of different tissues shows species-specific variation, it could be successfully used for the identification of fish species (Shengming et al. 1988). Higher number of esterase bands was found in the Asian catfish which seems to indicate the higher variation than the African catfish. Differences in the tissue specific expression of esterase isozymes were used to determine the species. Al-Amin et al. (2005) reported that isozyme banding pattern of the intestine could be used for the identification of two species of Pangasius ( $P$. sutchi and $P$. pangasius). The same tissue of different species often show differential expression pattern. As for example, forebrain and midbrain of African catfish showed only one 
esterase band (Est-4) whereas Asian catfish showed all five esterase bands. It is therefore interesting to note that esterase activity in brain was much higher and diversified in the Asian catfish than that of the the African catfish.

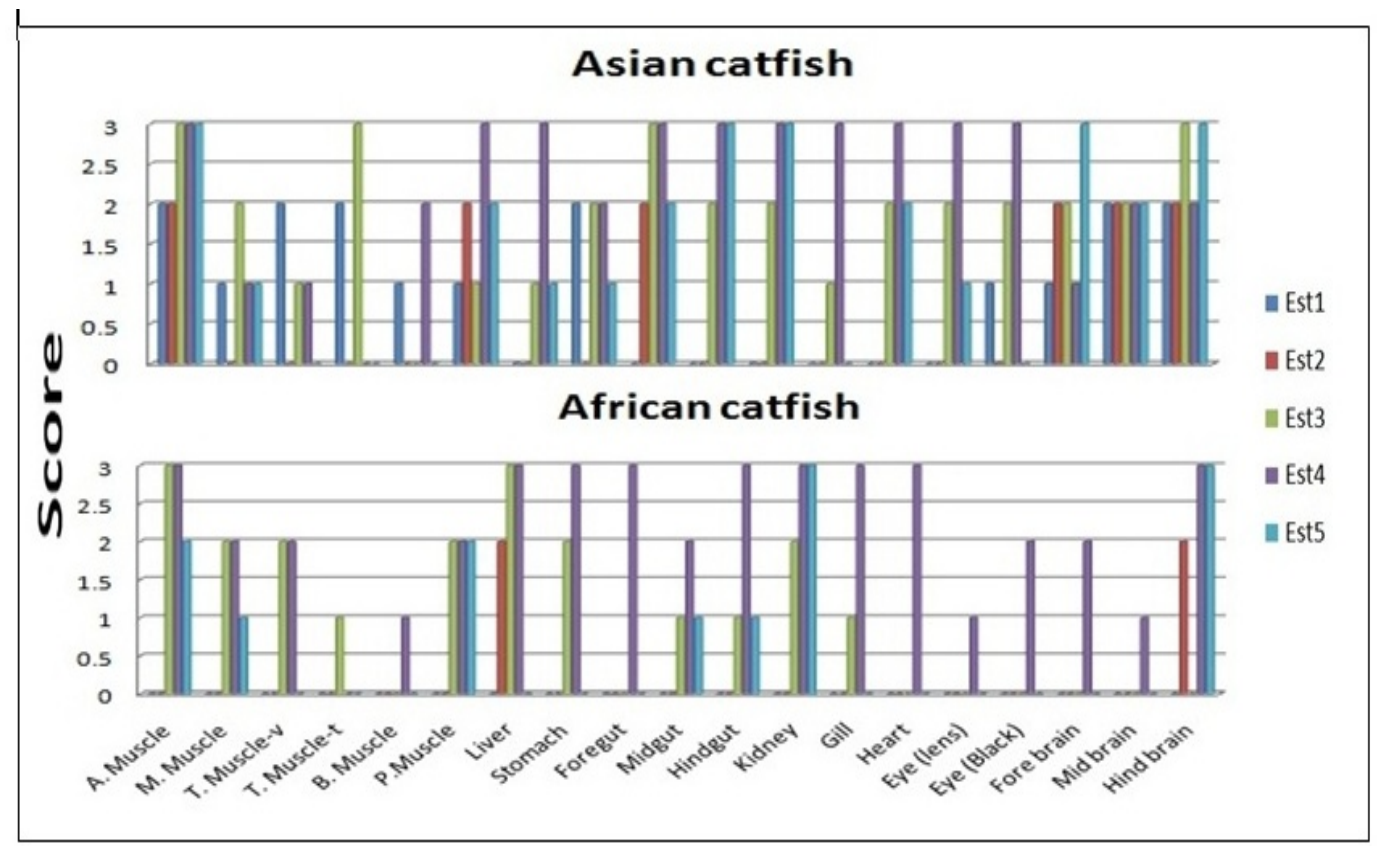

Fig. 1. Comparison of esterase isozyme banding patterns in the Asian and African catfishes on a three point intensity variation scale.

Est-3 and Est-4 were frequently present in most of the tissues. There was no difference in the gill tissue of the catfishes. Comparing different tissues of $C$. batrachus and C. gariepinus it was found that the same tissue of them showed differential expression in terms of the switch on or off of the specific allele and intensity. Two species of Anabas (A. testudineus and A. oligolepis) were identified using esterase bands of liver, kidney, skeletal muscle, heart and egg (Ramaseshaiah and Dutt 1984). Whereas four species of Clarias (viz. C. batrachus, C. gariepinus, C. macrocephalus and C. meladerma) were identified using polymorphic loci of ten isozymes (viz. AAT, ADH, GPI, GPD, IDHP-1, LDH, $M D H, M P I, P G M$ and PROT) in the population (Na-Nakorn et al. 2002). The present results would add further information to the catfish isozyme variability.

Concluding remarks: The present study was dealt with the variability pattern in esterase isozymes to describe the electromorphs of an individual representative. Results suggest that esterase isozyme could essentially be used as a marker to understand genetic makeup of a species for any conservation effort as well as species identification and selection. 


\section{LITERATURE CITED}

AHUJA, M.R., SCHAWB, M. and ANDERS, F. 1977. Tissue-specific esterases in the xiphophorine fish Platypoecilus maculates, Xiphophorus helleri and their hybrid. Biochem. Genet. 15(7-8): 601-610.

AL-AMIN, M., SUFI, G.B. and SHAHJAHAN, R.M. 2005. Esterase isozyme pattern in Pangasius pangasius and P. sutchi. J. Biol. Sci. 14(2): 193-196.

AYLTON, S.T. and SUZANA, S.O. 2005. Evidence for a natural hybrid of peacock bass (Cichla monoculus $v$ s Cichla temensis) based on esterase electrophoretic patterns. Genet. Mol. Res. 4(1): 74-83.

BAGLOLE, C.J., GOFF, G.P. and WRIGHT, G.M. 1998. Distribution and ontogeny of digestive enzymes in larval yellowtail and winter flounder. J. Fish Biol. 53: 340-365.

BARUA, S., ALAM, M.M.R. and SIMONSEN, V. 2004. Genetic variation in four hatchery populations of Thai pangas, Pangasius hypothalamus of Mymensingh region in Bangaladesh using allozyme marker. Pakistan J. Biol. Sci. 7(2): 144-149.

BEGUM, R.A., BHADRA, S.C., SHAHJAHAN, R.M., ALAM, M.S. and BEGUM, A. 2008. Esterase banding pattern in differant tissues of Pangasius hypophthalmus (Sauvage, 1878). Bangladesh $J$. Zool. 36: 287-294.

CALlAGHAN, A., BOIROUX, V., RAYMOFLD, M. and PASTEUR, N. 1994. Prevention of changes in electrophoretic mobility of overproduced esterase from organophosphate-resistant mosquitoes of the Culex pipiens complex. Med. Veter. Entom. 8: 391-394.

COURTENAY, W.R.J. 1970. Florida's walking catfish. Ward's Nat. Sci. Bull. 10: 1-6.

FERguson, A., TAgGart, J.B., PRODhOHL, P.A., MCMEel, O., ThOMPSON, C., STONE, C., MCGINNITY, P. and HYNES, R.A. 1995. The application of molecular markers to the study and conservation of fish populations, with special reference to Salmo. J. Fish Biol. 47: 103-126.

FERGUSON, A. 1980. Biochemical Systematics and Evolution. Blackie, Glasgow, London, England. $194 \mathrm{pp}$.

HARRIES, S.E.G., DILLION, R.T., SANDIFER, P.A. and LASTER, L.J. 1990. Electrophoresis of isozymes in cultured Penaeus vannameri. Aquacul. 85: 330-335.

HONGTUO, F., DEQUAN, Z. and TINGTING, W. 1993. Isozyme of Oreochromis aureus. Aquacul. 110: 61-70.

HIRJI, K.N. and COURTNEY, W.A.M. 1983. Non specific carboxylic esterase activity in the digestive tract of the perch, Perca fluviatilis. J. Fish Biol. 22(1): 1-7.

JOHNSON, F.M. and DENNISTON, C. 1964. Genetic variation of alcohol dehydrogenase in Drosophila melanogaster. Nature 204: 904-907.

KNOWLES, C., ARUVKAR, S.K. and HOGAN, J.W. 1968. Electrophoretic seperation of fish brain esterase. J. Fish. Res. Board Canada 25: 121-129.

NA-NAKORN, U., SODSUK, P., WONGRAT, P., JANEKITKARN, S. and BARTLEY, D.M. 2002. Isozyme variation among four species of the catfish genus Clarias. J. Fish Biol. 60: 1051-1057.

RAMASESHAIAH, M. and DUTT, S. 1984. Comparative electrophoretic studies of Anabas testudineus and A. oligolepis (Osteichthyes: Anabantidae) (climbing perch) from lake Kolleru, Andhra Pradesh, India. Hydrobiol. 119: 57-64.

REINITZ, G.L. 1977. Electrophoretic distinction of rainbow trout (Salmo gairdneri), west-slope cutthroat trout (S. clarki), and their hybrids. J. Fish. Res. Board Canada 34: 1236-1239.

RICHARDSON, B.J., BAVERSTOCK, P.R. and ADAMS, M. 1986. Allozyme Electrophoresis; A hand book for Animal Systematics and Population studies. Academic press Inc.

ROBINSON, A.S. 1986. Genetic sexing in Anopheles stephensi using dieldrin resistance. American Mosq. Control Assoc. 2: 93-95. 
RONGON, X., TEUGELS, G.G., GUYOMARD, R., GALBUSERA, P., ANDRIAMANGA, M., VOLCKAERT, F. and AGNESE, J.F. 1998. Morphometric and allozyme variation in the African catfishes Clarias gariepinus and C. anguillaris. J. Fish Biol. 53: 192-207.

SHAHJAHAN, R.M., KARIM, A., BEGUM, R.A., ALAM, M.S. and BEGUM, A. 2008. Tissue specific esterase isozyme banding pattern in Nile tilapia (Oreochromis niloticus). Univ. J. Zool. Rajshahi Univ. 27: 1-5.

SEN, T.K. 1985. The fish fauna of Assam and neighbouring North-eastern States of India. The zoological survey of India, miscellaneous publication, occasional paper No. 64. Calcutta. $217 \mathrm{pp}$.

SHEngming, H., CHANGGEnG, Q. and THUKUI, T. 1988. Comparative studies on the electrophoregram of esterase isozyme and lactate dehydrogenase of Carassius aukatus gibelio bloch and Carassius sp. Zool. Res. 9: 69-78.

SIFA, L., WANGI, C. and BIYUN, Z. 1993. Variation of morphology and biochemical genetics markers among population of blunt snout bream (Megalobrana mblycephala). Aquacul. 111: 117-127.

SOLOMON, D.J. and CHILD, A.R. 1978. Identification of juvenile natural hybrids between Atlantic salmon (Salmo salar L.) and trout (S. trutta L.). J. Fish Biol. 12: 499-501.

TEUGELS, G.G. 1996. Taxonomy, phylogeny and biogeography of catfishes (Ostriophysi, Silurroidei): an overview. Aquatic Living Res. 9: 9-34.

TEUGELS, G.G., GUYOMARD, R. and LEGENDRE, M. 1992. Enzymatic variation in African clariid catfishes. J. Fish Biol. 40: 87-96

WITZEMANN, V. and BOUSTEAD, C. 1981. Distribution of acetylcholinesterase molecular forms in brain, nerve and muscle tissue of Torpedo marmorata. Neurosci. Letter 26: 313-318.

(Manuscript received on July 15, 2011; revised on February 7, 2012) 